\title{
TINERII, BISERICA ŞI PROVOCĂRILE SOCIETĂTII CONTEMPORANE
}

\author{
Brânzea Nicolae* \\ Radomir Marius Sorin**
}

Motto: Știi unde poți căpăta definiția omului? - te întreb. În templu. În biserică. Acolo eşti comparat cu Dumnezeu, fiindcă exprimi chipul și asemănarea Lui. Dacă Biserica ar dispărea din istorie, istoria n-ar mai avea oameni. Ar dispărea și omul. În biserică afli că exiști.

Petre Țuţea

\begin{abstract}
The relationship between the Church, young men and modern society involves a deep knowledge of the realities that Church's mission have from being up to existence, between past, present and future, as well as an approach with immediate applicability in the sphere of the human person without removing the functions of his soul, placing it permanently in Christ's and the Holy Fathers Model. Antinomy, dogma and practice (praxis) become a coordinate system in the missionary process of the Christ's Church, where its first target are young men of contemporary society with all known and unknowns raised by such a delicate topic. The determined values of divine intervention in time should be essentially immutable human laws in their essence but with improvements in the formal spectrum, giving as superscript tag the divine love with strict nomination within the sphere of the human person that accept it. The Church, the young people and the world, can reflect only under the aspect of Holy Trinity, of dogma, antinomy, Christology, prophecy, Holy Spirit analogy and eschatology, on its way, in this case of the young man, from the face to the resemblance.
\end{abstract}

Keywords: Church, young people, youth, society, orthodoxy, Bible, Jesus Christ, moral, ethics, bio-etihics, salvation, Kingdom of Heaven, temple, globalisation, secularization, mission, cosmos, love, divine, spirituality, time.

\footnotetext{
* PhD, Associate Professor, University of Piteşti, Faculty of Orthodox Theology, Piteşti, Romania.

** PhD, University of Piteşti, Faculty of Orthodox Theology, Piteşti, Romania.
} 


\section{Prolegomena}

Societatea modernă și postmodernă în care trăim astăzi pendulează frenetic între principii și valori deopotrivă contradictorii, pe care de cele mai multe ori le promovează fără cunoștință de caz ci în virtutea unor definiții apriori legate de libertatea umană și ce reprezintă cu adevărat aceasta. Așa se face că asistăm de multe ori, privați chiar de cel mai de bun preț al ființei noastre - anume tocmai libertatea de care facem atât de mult caz - la o mișcare dirijată prin care se încearcă de fapt tocmai îngrădirea libertății umane prin legi paradoxale, libertine și nicidecum voluntariste. Pioșenia este astfel nimicită, libertatea este îngrădită, păcatul este legiferat, religia plafonată, credinţa batjocorită sub pretextul adevărului științific ${ }^{1}$, ce postulează ipoteze și teorii ce nu pot fi niciodată demonstrate pe deplin, ființa umană este redusă la un numeral perfid, un CNP, o diviziune a umanității, o masă biologică neglijabilă, nu-i aşa, în vastul univers, Dumnezeu fiind catalogat de cele mai multe ori drept Unul dintre extratereștrii antici, ceea ce înseamnă că și El, la fel ca și noi, a fost la rândul lui creat de Cineva, sofisme fără noimă și fără logică așa cum ne explică foarte clar însuși părintele logicii formale, filosoful Aristotel.

Această realitate perfidă devine un complex, un labirint, la capătul căruia Minotaurul ucide in nuce orice suflet pe care reușește să-1 ademenească. Și pentru că, psihicul tinerilor din zilele noastre este tocmai în perioada lui de reset, de "repornire e la zero", aceștia sunt și victimele preponderente. Tocmai de aceea misiunea Bisericii cu privire la tinerii zilelor noastre este una extrem de grea și plină de neprevăzut, o misiune cu adevărat apostolică, menită să-1 călăuzească pe tânăr de la pieire la mântuire și chiar la isihie $\stackrel{2}{\text {, }}$ aspecte asupra cărora vom insista în cele ce urmează. Pentru a înțelege scopul, mijloacele și metoda prin care Biserica trebuie să

1 Kallistos Ware, Educaţia Teologică în Scriptură şi la Sfinţii Părinţi, traducere de Anişoara Carol, în „Studii Teologice”, Seria a II-a, XLVI, 1994, nr. 4-6, p. 89.

${ }^{2}$ Ibidem, p. 90. 
lupte pentru salvarea tinerilor din ghearele nemiloase ale societății globalizate în care trăim, trebuie să facem o incursiune în vastul izvor al Revelației divine insistând pe înțelepciunea Cuvântului lui Dumnezeu întipărit în Sfânta Scriptură. Înainte de a face asta însă trebuie să stabilim cu precizie ce reprezintă tânărul și tinerețea.

\section{Tinerețea între spiritualitate şi fizilologie}

Din punct de vedere fiziologic, psihologic și spiritual tinerețea este etapa de vârsta în care sub raport fizic și psihic se definitivează și se perfecționează calitativ componentele tuturor sistemelor organismului, și mai ales ale creierului. Sporesc forțele fizice și mai ales „forțele" creierului, baza naturală a unei activități fizice și spirituale mai valoroase și mai eficiente. Tinerețea este atât o etapă de dezvoltare, perfecționare și manifestare multidimensională, cât și o stare de spirit cu deosebite semnificații și tendințe valorice, acționale și creative. Este o „vârsta de aur”, frumoasă, plină de entuziasm, elan și exuberanță; este o vârsta în care se manifestă încrederea în forțele proprii, în om, în viață; este vârsta creativității şi împlinirilor pe plan personal, profesional, social și mai ales spiritual, vârsta asumării responsabilităților personale, ființiale, ontologice. Desigur, toate aceste caracteristici valoroase și încă multe altele nu se realizează de la sine, ci sunt rezultatul unor eforturi susținute și responsabile de învățare, de activitate profesionala, socială și spirituală.

Tinerețea este perioada perfecționării psihice, a stabilirii echilibrului funcțional optim, mecanismele de realizare si reglare a acțiunilor și comportamentului dovedind performanțe superioare. Toate procesele psihice se dezvoltă la un înalt nivel de calitate și eficiență. De aceea Biserica trebuie să țină cont de procesele psihice cognitive și afective, de motivație și de motive, de profilul caracterului personal (atitudinile și convingerile personale), de dezvoltarea calitativă multidimensională a personalității tânărului determinată de trăsături specifice vârstei, de promovarea și conștientizarea responsabilităților sociale, de particularități pozitive, de fondul spiritual comun, de trecerea individului la forma 
definitorie pentru omul adult, aceea de subiect al activităţii socialspirituale, ceea ce-i conferă un rol și un statut superior în ansamblul valorilor, activităților și relațiilor sociale și spirituale. În acest context, Biserica trebuie să înţeleagă și să accepte fenomenul de schimbare treptată, de la mic la mare, de la prunc, copil, adolescent, tânăr, matur, vârstnic și bătrân, pe fundalul unei înțelegeri și cooperării adecvate între generații după cum remarca poetul grec Euripide (480-406 î.Hr.): Puterea celor tineri stă în faptă, a celor vârstnici în chibzuință.

Valorile pe care tânărul le îmbrăţişează pot părea neglijabile sau ,ciudate" pentru persoanele mature. Unele valori au parte de o mai mare emfază şi sunt mai bine articulate (de exemplu, loialitatea faţă de un grup, libertatea de expresie sau spiritul de aventură), iar altele sunt mai vagi sau mai neinteresante (de exemplu, conştiinciozitatea, disciplina, loialitatea sau toleranță). Prinși între două identităti, între ipostaza copilului şi aceea a adultului, căutându-şi propria identitate, în drumul lor către maturizarea spirituală $\breve{3}^{3}$ adolescenții vor răspunsuri la o serie de întrebări mărunte din punctul de vedere al adultului, dar extrem de tulburătoare pentru ei, răspunsuri pe care nu le caută la părinţi sau la rude, ci la prietenii de la şcoală sau din cartier, la eroii din revistele la modă pe care le citesc, la vedetele mai mult sau mai puţin autentice promovate de mass-media și la Biserică. În societatea ${ }^{4}$ actuală, supusă unui ritm rapid de dezvoltare, pe lângă provocările determinate de trecerea prin această vârstă a contradicţiilor, apar alte provocări impuse de lumea contemporană. Astfel, probleme legate de aspectul exterior (cum mă îmbrac, ce se poartă), de comunicarea cu adulţii, de drepturi şi responsabilităţ̧i, de preocupări pentru viitoarea carieră, de succesul sau insuccesul şcolar, de întâlnirile sentimentale, de independenţă şi autonomie, de integrarea într-un grup, etc.

${ }^{3}$ Hristu Andrustos, Sistem de morală, Sibiu, 1947, p.105-106.

4 Şerban Ionescu, Morala ortodoxă faţă cu celelalte morale confesionale, Bucureşti, Edit. Solidaritatea, 1941, p. 169. 


\section{Sfânta Scriptură- adevărul şi metafora tinereţii}

Fără pretenția unui discurs exhaustiv, vom încerca în cele ce urmează să privim tânărul prin ochii Bisericii, în lumina canonului Sfintei Scripturi, în raport cu societatea actuală și bineînțeles cu exemplele aferente, insistând pe antinomia dintre tânărul bogat (Matei 19, 16-22) și tânărul Apostol și Evanghelist Ioan, Apostolul iubirii, cel care și-a așezat capul pe pieptul Mântuitorului la Cina cea de Taină și pe care îl iubea Iisus (Ioan 21, 20) pentru fecioria și neprihănirea lui de tânăr fără de meteahnă fizică și spirituală. Nu vom trece cu vederea nici tinerețea Mântuitorului Hristos, pe care Îl oferim drept singurul, unicul și adevăratul exemplu tuturor celor care își îndreaptă privirile către idolii moderni promovați până la exacerbare de mass-media (vezi cavalerii Jedi din universul Star Wars sau eroii Marvel precum zeul Thor, Hulk, Spiderman, Ironman, Superman, Batman, Deadpool, Antman, etc.)

Am ales cele două modele pentru că ele sunt concludente pentru zilele și societatea în care trăim: pe de o parte sunt tinerii cu o atitudine pe care am numit-o simbolic „selfie" și care se raliază cu tânărul bogat din pildă iar pe de altă parte sunt tinerii care vin să stea la pieptul Mântuitorului prin prezența lor permanentă la rugăciunea liturgică, făcându-se părtași morții și Învierii lui Hristos, Domnul nostru.

Omul, în speță tânărul, eroul expunerii noastre, are un scop precis definitivat de planul lui Dumnezeu, ce constă în sfințirea noastră: voia lui Dumnezeu aceasta este: sfințirea noastră; să vă feriți de desfrânare, ca să știe fiecare din voi să-și stăpânească vasul său în sfințenie și cinste, nu în patima poftei cum fac neamurile care nu cunosc pe Dumnezeu (1 Tesaloniceni 4, 3-5). Și acest plan al lui Dumnezeu trebuie să ne călăuzească pașii încă din perioada scurtă a tinereții noastre, având în inimă și în suflet ${ }^{5}$ cuvintele înțeleptului Solomon care zice: Adu-ti aminte de Ziditorul tău în zilele tinereții tale, înainte ca să vină zilele de restriște și să se apropie anii despre care vei zice: $\mathrm{N}$-am nici o plăcere de ei ...

${ }^{5}$ Ioan Zăgrean, Morala creştină, Cluj-Napoca, 2002, p. 64. 
(Eclesiastul 12,1). Pentru ca aceste îndemnuri, scoase din paginile Sfintei Scripturi, să ajungă a fi scrise precum tablele legii în inima și sufletul tânărului din zilele noastre trebuie ca Biserica să-și focalizeze eforturile către cugetul, inima și sufletul acestuia, pentru a-1 smulge din ghearele unei lumi în care se promovează egoismul, minciuna, desfrânarea, ura și toate non-valorile ce nu fac altceva decât să influențeze negativ viața tinerilor. Toate aceste piedici i-au îndepărtat pe tineri de adevăr, de credință și de Biserică, neștiind să se folosească de libertate cu care au fost înzestrați de Creatorul lor şi necunoscând cuvintele Sfântului Apostol Pavel: Toate imi sunt ingăduite, dar nu toate îmi sunt de folos (I Corinteni 6, 12).

Tânărul poate găsi tot ceea ce caută doar în Biserica lui Hristos, ca și cum ar sta în faţa lui Dumnezeu ${ }^{6}$, căci aceasta ca o mamă își adapă pururea fiii cu veșnicele și dumnezeieștile ei învățături. Avantajele de a merge la Liturghie sunt unele concrete și cât se poate de adaptate realităților contemporane, dar mereu cu perspectiva împărăției cerurilor: V-am scris vouă, tinerilor, pentru că sunteți tari și cuvântul lui Dumnezeu petrece în voi și ați biruit pe cel viclean (I Ioan 2,14). Tinerețea este o perioada așa de scurtă în comparație cu întreaga viată sau în comparație cu eternitatea. Totuşi această scurtă perioadă este vremea marilor realizări sau marilor dezamăgiri și regrete. Este vremea marilor decizii: Bucură-te, omule, cât ești tânăr și inima ta să fie veselă în zilele tinereții tale și mergi în căile inimii tale și după ce-ti arată ochii tăi, dar să știi căă, pentru toate acestea, Dumnezeu te va aduce la judecata Sa. Alungă necazul din inima ta și depărtează suferințele de trupul tău, căci copilăria și tinerețea sunt deșertăciune (Eclesiastul 11,9).

La tot pasul întâlnim acel model de tânăr (ca cel din pilda tânărului bogat), care vine la biserică pentru a se îndreptăți pe sine, ignorând totalmente aspectul primordial al smereniei hristice și persiflând întrebare existențială ce să fac? transformând-o în banalul ce pot face eu?, adică cu ce sunt eu de vină atâta timp cât totul este dat de la Dumnezeu, ca un destin implacabil? $\mathrm{Cu}$ alte cuvinte acest

6 Dumitru Stăniloae, Chipul nemuritor a Lui Dumnezeu, Craiova, Edit. Mitropoliei Olteniei, 1987, p. 63. 
fals model de tânăr își argumentează după bunul plac lenea sufletească în care se găsește, eschivându-se de la propriile îndatoriri pe care le are față de Dumnezeu și față de aproapele său. Tocmai de aceea Biserica îi pune întrebarea, după exemplul Mântuitorului: De ce-Mi zic bun? Nimeni nu este bun decât numai Unul Dumnezeu (Matei 19, 17). Este atitudinea prin care Biserica îi atrage atenția că stă în fața Trupului viu al lui Hristos, în care viază mădularele Sale vii, ca deținătoare a plinătăţii harului divin, stâlp și temelie al adevărului. Ignorarea acestui adevăr fundamental va face imposibilă colaborarea dintre acest gen de tineri și Biserică, dovadă fiind comportamentul exacerbat de pe rețelele de socializare al acestora față de Biserica mamă, incapabili fiind să se lepede de falsa bogăție a distracției, de a-și lua crucea și de a-I urma lui Hristos. Chiar şi așa Biserica nu se împotrivește acestui model de tineri ci încearcă până la capăt, ca o mamă iubitoare, să-și aducă fiii rătăciți pe Calea, Adevărul și Viața care este Hristos.

O primă luptă o dă Biserica în încercarea ei de a comunica adecvat cu familia creștină, locul unde se va forma caracterul moral și personalitatea fiecărui tânăr. Familia este ținta principală a învățăturii Bisericii, prin care se încearcă crearea unei legături sublime între preotul-duhovnic și familia creștină, astfel încât, prin spovedanie, sfintele taine, ierurgii, vizite pastorale și mai ales Sfânta Liturghie să-i prezinte tânărului pe Dumnezeu Părintele iubitor (vezi pilda fiului risipitor) și nu ca pe un Judecător pornit doar spre canoane şi pedepse. Modelul duhovnicului trebuie să fie unul pozitiv, de pecetluire duhovnicească ${ }^{7}$. Importanța exemplului pozitiv în procesul de educație se bazează pe tendința înnăscută a copilului de a imita. Din frageda copilărie el imită persoanele care ii sunt mai apropiate: părinți, bunici, frați. În perioada adolescenței sfera de influență a exemplelor educative se extinde, copilul își găsește modele de viață în rândul educatorilor, profesorilor, cunoștințelor, preotului și mai ales modelele sfinților care au fost și ei oameni asemenea nouă cu aceleași slăbiciuni, suferințe, aceleași neputințe,

7 Sfântul Simion Noul Teolog, Scopul vieţii creştine, Iaşi, Edit. Pelerinul, 2002, p. 56-57. 
dar poate ceva mai multă voință. Numai așa Biserica poate salva sufletul tânărului evitând avertismentul înțeleptului Solomon din Pilde:

\begin{abstract}
„Odată stam la fereastra casei mele şi priveam printre gratii și am zărit, printre cei lipsiți de minte, un tânăr fără pricepere. El trecea pe uliță pe lângă colțul casei ei (a femeii străine) și se îndrepta către locuința ei. Era în amurgul serii unei zile, când se lasă umbra și întunericul nopții. Și iată o femeie îl întâmpină, având înfățișare de desfrânată și prefăcătorie în inimă; Aprigă și de neținut în frâu, picioarele ei nu se mai odihneau în casă; Când în casă, când afară, stând la pândă lângă orice colț. Ea îl apucă și-1 sărută cu o căutătură obraznică... El începu să meargă dintr-o dată după ea, ca un bou la junghiere și ca un cerb care se zorește spre capcană” (Pilde 7, 6-22).
\end{abstract}

Dumnezeu nu impune restricții care să nă provoace durere și nefericire ci dimpotrivă, ca un Părinte cu adevărat iubitor ne îndrumă pașii spre fericirea cea cu înțelepciune dobândită făcând apel la conștiința morală a fiecăruia dintre noi: Bucură-te, omule, cât ești tânăr și inima ta să fie veselă în zilele tinereții tale și mergi în căile inimii tale și după ce-ti arată ochii tăi, dar să știi că, pentru toate acestea, Dumnezeu te va aduce la Judecata Sa (Eclesiastul 11, 9). Această conștiință morală este de fapt glasul lui Dumnezeu din om, ea manifestându-se în principiu pe plan afectiv, emoțional iar mai apoi în plan moral, legiuitor. In ceea ce privește partea intelectuală, conștiința se dezvoltă în puterea de judecată a gândurilor și a deciziilor morale. Conștiința ca manifestare a întregii ființe spirituale a omului, este accesibilă și în același timp capabilă de dezvoltare și formare, mergând împreună cu întreaga mișcare și viaţă spirituală, până când se va contopi "în marea nesfârșită $a$ iubirii lui Dumnezeu",

În morala ortodoxă, personalitatea creștină se formează prin puterea iubirii și a libertății voinței. Atât dragostea față de aproapele cât și conștiința de creștin duce către sentimentul de toleranță și de

${ }^{8}$ Andrei, Arhiepiscopul Alba Iuliei, Dragoste, libertate şi sex responsabil, Alba Iulia, Editura Reîntregirea, 2005, p. 16. 
milă creștină. Tabloul adevăratului suflet de tânăr ortodox ni-1 înfățișează apostolul neamurilor în imnul dragostei atunci când ne spune: dragostea îndelung rabdă, dragostea este plină de bunătate, nu pizmuiește, nu se laudă nu se trufeşte, nu se poartă cu necuviință, nu caută ale sale, nu se gândește rău, nu se bucură de nedreptate ci se bucură de adevăr. Toate le suferă, toate le rabdă. Dragostea nu cade niciodată (I Corinteni 13, 4-8).

În Sfânta Scriptură găsim numeroase modele de tineri și tinerețe drept de urmat atât in Vechiul Testament cât și în Noul Testament. Așa luăm act de tânărul Iosif, cel ce a tâlcuit visele lui Faraon în Egipt, de tânărul Iosua, fiul lui Navi, cel numit căpetenie peste oastea lui Israel de Moise odată cu fuga din Egipt și trecerea prin Marea Roșie, de Otniel, fiul lui Chenaz din seminția lui Iuda, cuceritorul cetății Debirului, de tânărul levit din seminția lui Iuda, cel ce a fost numit preot în casa lui Mica, punând capăt slujirii idolești, de tânăra Rut moabiteanca alipită la poporul lui Israel și menţionată în genealogia lui Hristos, de regele cel tânăr și foarte frumos Saul, primul rege al lui Israel, de regele cel tânăr și blond David, de regele tânăr și înțelept Solomon, de tânărul Țadoc și cele 22 de căpetenii de viteji din oastea lui Israel, urmașii regelui David, de tânărul rege Iosia din seminția lui David, cel ce a curățat poporul de idoli, de tânărul Elihu cel ce apară dreptatea lui Dumnezeu în istorisirea dreptului Iov, de tânărul Elisei, ucenicul sfântului proroc Ilie Tesiteanul, de tânărul prooroc Ieremia cel chemat la profeție, de tânărul proroc Zaharia, de tânărul Tobie, fiul lui Tobit, de tânărul Zorobabel cel care binecuvântează Slava lui Dumnezeu, de cântarea celor trei tineri din Babilon și a tânărului Daniel, cel din pruncie chemat la proorocie pentru a o scăpa de la moarte pe Susana, de tânărul ce urmărea pe Hristos atunci când a fost prins de arhierei pentru a fi judecat (apostolul și evanghelistul Ioan), de tânărul din Nain, de tânărul din pilda fiului risipitor, de tânărul arhidiacon Ștefan, cel dintâi mucenic creștin, de tânărul Saul devenit Sf. Apostol Pavel, de tânărul Eutihie cel înviat de Apostolul Pavel atunci când ațipise în noapte la predica apostolului și căzând s-a lovit și a murit. 
Asupra tuturor acestora tronează desigur tânărul Apostol și Evanghelist Ioan, ucenicul cel mult iubit, Apostolul iubirii creștine, singurul dintre Apostoli ce s-a învrednicit de moarte naturală și nu martirică, pentru că mult a iubit și pentru că mult s-a smerit. Aceeași iubire o dă Iisus Hristos tinerilor de astăzi care se ridică la asemănarea cu apostolul și evanghelistul Ioan, adică sunt feciorelnici trupește și sufletește, iubesc fără opreliște iar această iubire creștină nu are nimic de a face cu sexul păcatului ci cu sizighia familiei, sunt smeriţi cu inima și vin la sânul Bisericii precum odinioară apostolul a șezut la sânul Mântuitorului. Iată modelul tinerilor creștini de astăzi, apostolul și evanghelistul Ioan, om al smereniei, al iubirii nepătimașe, al curăției, al postului, al rugăciunii, al cuvântului și al duhovniciei. Apostolul și Evanghelistul Ioan este singurul care scrie nu doar o evanghelie deosebită de celelalte trei, o evanghelie a începutului și a sfârşitului, o evanghelie profund duhovnicească, centralizată pe euharistie și Înviere, coroana ${ }^{9}$ Sfintei Scripturi, ci el ne scrie și Apocalipsa sau Revelația de care singur s-a învrednicit și pe care ne-a împărtășit-o cu dragoste tuturor, spre a noastră îndreptare și mântuire. Așa cum apostolul Ioan a fost martor lui Hristos, de la minunata lui alegere ca apostol, la vederea luminii Taborice, la rugăciunea din grădina Ghetsimani, la falsul proces, la răstignire când primește în grijă pe Maica Domnului și a noastră a tuturor, până la Înviere și la Revelație, ca martor direct al Împărției ce va să fie, asemenea viața, activitatea și răsplata lui este și darul tuturor acelor tineri care îl urmează astăzi și în veci pe Hristos cu aceeași stăruință, dăruire și iubire. El este tânărul ce s-a îmbogățit cu Împărăția lui Hristos lepădând toate cele lumești antonomic tânărului care agonisind toate cele pământești și pierde pe cele duhovnicești, deși i se atrage atenția stăruitor să conștientizeze că se află în faţa Dreptului Judecător, pe Care Îl ignoră din mândrie și prea multa iubire de sine. Prin ce își va indrepta tânărul calea sa?, întreabă Psalmistul rege David și tot el

${ }_{9}$ George Arthur Buttrick, Walter Russel Bowie, Paul Schrer, John Knox, Samuel Terrien şi Nollan B. Harmon, The Interpreter's Bible, A commentary in twelve volumes, vol. VIII (New York: Abingdon Press, 1952), p. 437. 
ne răspunde: Prin păzirea cuvintelor Tale(Psalm 118, 9), făcând trimitere precisă la înțelepciunea cea întru Dumnezeu despre care ne zice regele înțelept Solomon:

„Şi de poftește cineva să aibă știința întinsă, înțelepciunea știe cele trecute și întrezărește cele viitoare, ea știe întorsăturile cuvintelor și dezlegările întrebărilor; ea cunoaște de mai înainte semnele și minunile și întâmplările vremurilor și ale sutelor de ani. Drept aceea am hotarat să mi-o prind tovarășă îin viață, fiindcă șstiu că mă va sfătui cele bune și-mi va fi mângâiere în griji și în necazuri. Și voi avea, prin ea, mărire în adunări; și deși sunt tânăr, voi avea cinste în fața celor bătrâni. Mă vor găsi pătrunzător la judecăți, și voi apărea uimitor în fața celor puternici" (Pilde 8, 8-11).

În ziua de azi este din ce în ce mai greu pentru preoți să-i apropie pe tineri de Biserică, tocmai pentru că tinerii sunt crescuți de mici în afara Bisericii. Deci misiunea preoților ar trebui să înceapă întâi de la părinți, pentru ca apropiind părinții de Biserică, cu siguranță aceștia la rândul lor vor încerca să-și apropie și copii de Dumnezeu; iar un copil dus de mic la Biserică și crescut în Duhul Bisericii, cu siguranţă se va apropia de Dumnezeu din ce în ce mai mult pe măsură ce va crește. Bineînțeles că nu tot timpul se întâmpla așa, tocmai pentru aceasta, Biserica a căutat și alte metode pentru a face misiune în rândul tinerilor, și anume înființarea unor asociații, și dezvoltarea unor programe dedicate lor exclusiv. Prin toate acestea sunt chemați la misiune nu doar preoții, ci și tinerii.

Un alt lucru important de reținut este că Biserica nu caută să îngrădească libertatea cum cred mulți tineri din ziua de azi. După cum Sfântul Apostol Pavel ne îndeamnă Toate să le încercați; ține-ți ce este bine; feriți-vă de orice infățișare a răului ( I Tes. 5, 20), așa și Biserica încurajează libertatea tinerilor, căutând să le descopere ce este bine, dar nu orice libertate. Tot Sfântul Apostol Pavel ne zice să nu folosim libertatea ca prilej de a sluji trupului, ci unul altuia prin iubire (Gal. 5, 13).

Chemarea Bisericii este chemarea hristică de a ședea cu capul pe pieptul Mântuitorului asemenea apostolului și evanghelistului Ioan, căci a sta cu capul pe pieptul lui Iisus înseamnă a trăi 
duhovnicește, născuți din apă și din duh ca în convorbire Mântuitorului cu dreptul Nicodim, adică a cunoaşte pe Dumnezeu prin experienţă directă, personală, prin trăirea duhovnicească ca răspuns firesc la viața orientată ascetic, de "a-L vedea pe Dumnezeu în lumină și prin lacrimile pocăinței”, adică tocmai forma cea mai înaltă de teologie ${ }^{10}$.

Cum poate câștiga Biserica pe tineri și care este forma de luptă duhovnicească cea mai redutabilă pe care trebuie ca aceasta să o poarte dacă nu postul și rugăciunea căci prin rugăciune noi putem așadar, să îi câștigăm, puțin câte puțin, din nevoință în nevoință, cu iubire stăruitoare, ca rod al credinței lucrătoare prin faptele ei bune. Căci, ne spune Evagrie Ponticul:

„rugăciunea este vorbirea minţii cu Dumnezeu [...] Când Moise încearcă să se apropie de rugul arzător, e împiedicat până nu dezleagă încălțămintea picioarelor. Cum nu te vei dezlega și tu de orice cuget pătimaş, dacă vrei să vezi pe Cel mai presus de orice simţire și înțelegere și să vorbești cu El?’"11.

Biserica trebuie să-i facă pe tineri dependenți de rugăciune cu osârdie mare, smulgându-i cu iubire nepătimașă din dependența lor de cele lumești, de pericolul drogurilor, al alcoolului, al sexului, al falsei comunicări prin mobile-cyber-internet, translocându-i din infernul patimilor în raiul desfătării, al Împărăției lui Dumnezeu cea plină de dreptate, de adevăr și de iubire dezinteresată. Acesta este muntele pe care Biserica trebuie să-l propună tinerilor din zilele noastre așa cum odinioară o face Sfântul Grigorie de Nyssa în monumentala lucrare Despre viața lui Moise.

Ori conștientizarea universului credinței creștin-ortodoxe nu se poate face decât prin participarea la Sfânta Liturghie întrucât viața

\footnotetext{
${ }^{10}$ Episcopul Maximos de Pittsburgh, Educaţia teologică în context ecumenic şi pluralist, traducere de Mihai Brânzea, în „Studii Teologice”, Seria a II-a, XLVII, 1995, nr. 1-3, p. 98.

${ }^{11}$ Ibidem, p. 75.
} 
duhovnicească a tinerilor nu se reduce numai la rugăciune ${ }^{12}$, ci trebuie să se împletească cu postul și cu spovedania, căci spovedania are rostul de a-i da omului posibilitatea să se smerească ${ }^{13}$ și să se sfințească: Fiți sfinți, că Eu, Domnul, sunt Sfânt (Levitic 11, 45).

Pentru o mai ușoară propovăduire și asumare a Evangheliei, tânărul ar trebui să renunțe la rigorile științifice cu care s-a obișnuit în instituțiile de învățământ căutând mai mult spre acea atitudine de simplitate mariologică ${ }^{14}$. Pentru a fi lumină lumii tânărul trebuie să coboare de pe piedestalul unei abordări așa zise academice ale discursului la un cu totul alt mod de abordare a lucrurilor, în duhul părinților bisericești, al smereniei pe înțelesul tuturor, dar mai cu seama al tinerilor, adică al celor asemenea lui, al aproapelui.

Asceza și viața duhovnicească la care am făcut referire în acest sens, capătă un aspect legat de libertatea omului de a se raporta la materie și de a fi cu adevărat liber ancorându-se în acea profunzime teologică a renunțării de sine prin întoarcerea lui de la materie spre Dumnezeu, ori aceasta ține de altfel de înseși condiția primordială a creației omului: din toți pomii raiului să mănânci, numai din pomul cunoștinței binelui şi al răului să nu mănânci, fiindcă în ziua în care vei mânca vei muri negreșit (Facere 2, 16-17). Prin urmare înțelegem că omul a fost creat cu o libertate deplină ${ }^{15}$.

Deși, în contemporaneitate, o viața virtuoasă e considerată ca fiind ceva demodat, iar ortodoxia - o oază a ignoranților şi ipocriților, care nu sunt capabili să realizeze un act de analiză critică, orice tânăr adus pe calea unei vieți ireproșabile stârnește cel puțin curiozitatea faţă de semenii lui ${ }^{16}$. A fi creștin ortodox în secolul XXI înseamnă a trăi jertfelnic, iar această jertfelnicie este cuantificată la aproximativ 100000 de victime din rândul creștinilor anual, mai

12 Paul Evdokimov, Rugăciunea în Biserica de Răsărit, Iaşi,Editura Polirom, 1996, p. 76.

${ }^{13}$ Mitropolitul Antonie al Surojului, Bucuria pocăinţei, Editura Marinească, p. 28.

${ }^{14} \mathrm{http}$ //viatalatara.wordpress.com/2009/06/02/rugaciunea-unui-teolog/

${ }^{15}$ Idem, Şcoala rugăciunii, Bucureşti, Editura Cartea Ortodoxă, 2006, p. 34.

16 Sfântul Grigorie cel Mare(Dialogul), Cartea regulei pastorale, Bucureşti,Edit. IBMBOR, 1996, p. 47. 
mult decât pe vremea celor mai crâncene persecuții. Într-o societate în care numai utilitatea contează, problemele reale sunt trecute la categoria: anexe ale vieții. Obsesia banului face pe mulți dintre contemporanii noștri să trăiască tensionați, într-o perpetuă răzbunare, într-un permanent război, pornit inclusiv de la premise imaginare. La nivel intelectual nimic nu are valoare decât numai utilitatea și productivitatea față de societatea care nu mai este una socială, ci managerială.

$\mathrm{Nu}$ cred să existe o postură mai delicată în lumea de azi ca cea a tânărului creștin ortodox, după modelul sublim al apostolului și evanghelistului Ioan, premisa incursiunii noastre de a deveni ochii și mintea clară a Bisericii ${ }^{17}$.

De aceea, după cum odinioară Hristos a chemat pe ucenicii Săi la apostolat sau la misiune, tot aşa Biserica lui Hristos îi cheamă pe tinerii ei la misiune sau la lucrare sfântă pentru mântuire. În acest sens, Sfầntul Ioan Gură de Aur († 407) spune:

„Şi tu eşti o lumină - nu pentru ca să ai lumina pentru tine singur, ci pentru ca să poți întoarce pe cei rătăciți. Căci ce folos de lumină, dacă ea nu le poate sluji celor ce şed în întuneric? Şi ce folos de un creştin, dacă el nu câştigă pe nimeni la fapta cea bună ?"18.

Este extrem de observabilă necesitatea misionarismului tinerilor în lumea secularizată de astăzi. Modul nostru de a fi trebuie să-1 arătăm cu demnitate şi curaj şi altora ${ }^{19}$. În această privinţă, Sfântul Apostol Pavel îi spune lui Timotei: Nimeni să $n u$ dispreţuiască tinereţile tale (I Timotei 4, 12).

Misiunea tânărului în societatea contemporană este una dificilă, dar pe cât de dificilă, pe atât este de sublimă. Activitatea sa în societatea contemporană înseamnă implicarea în problemele

${ }^{17}$ Ibidem, p. 78.

18 Sfântul Ioan Gură de Aur, „Cuvânt la Sfânta şi Marea Marţi: Împotriva lenevirii de a veni la Biserică”, în Omilii la Postul Mare, Bucureşti, Editura Anastasia, 1997, p. 41.

19 Antonie Bloom, Despre credinţă şi îndoială, Bucureşti, Editura Cathisma, 2007 , p. 59. 
actuale: globalizare, avort, contracepţie, corupţie, crimă organizată, terorism, imigrație, școală, cultură, filantropie, sănătate, etc., ori este bine știut că momentan doar în Biserica lui Hristos aceste cuvinte au o greutate convingătoare ${ }^{20}$.

\section{Concluzii}

Chiar trecând de vârsta la care ascultă necondiționat de părinții lor fără a-și pune întrebări, tinerii sunt în continuare influențaţi de familie - este primul mediu pe care 1-au cunoscut și rămâne un sprijin necondiționat pe parcursul vieții lor; familia înseamnă mai ales stabilitate. În raport cu societatea din afara familiei, tinerii își doresc deopotrivă să se integreze și să se distingă în cadrul ei, căutând pe de o parte să adopte noi mentalități răspândite de membri apreciați ai acesteia, pe de altă parte să acționeze diferit de restul lumii și să iș̣i afirme unicitatea.

Sunt tot mai mult apreciate persoanele care șochează și stârnesc controverse prin faptele și vorbele lor, iar societatea devine tot mai permisivă pentru acest tip de comportament și tot mai agresivă în urma unor fenomene gen "Colectiv". Noțiunea de tradiţionalism începe să fie apreciată ca fiind învechită și nenecesară iar normele de credință și morală încetățenite în timp sunt considerate a fi constrângeri învechite impuse nejustificat unei generații aflate în continuu progres.

Rebeliunea, al cărei scop de a dobândi drepturi și libertăți în cadrul unui sistem nedemocratic sau opresiv și-a pierdut acest scop în societatea actuală care permite libera exprimare și nu are constrângeri nejustificate, dar a rămas o formă de exprimare în continuare apreciată de persoanele tinere.

Se consideră că societatea în care trăim astăzi este mult mai departe de Dumnezeu și de valorile morale propovăduite de dogma creștină și este de înțeles că trebuie să se petreacă multe schimbări pentru a reveni pe calea cea bună. Poate că tânăra generație se va

20 Rose, Serafim, ieromonah, Cartea Facerii, crearea lumii şi omul inceputurilor, Bucureşti, Edit. Sofia, 2006, p. 91. 
întoarce la credință și prin resursele pe care le are, va schimba cursul pe care omenii au pornit, ajutând ca lumea să se abată de pe drumul rău pe care se află.

Stadiul societății actuale, cu toate coordonatele sale definitorii, nu poate surprinde Biserica, ea însăși chemata sa-și deschidă mesajul către oameni, atât ca persoane, cât și ca grup social. De aceea, Biserica trebuie să folosească toate strategiile misionare adaptate vectorului postmodern de exprimare existențială, spre a defini acel nou tip de umanism, destinat zilei de mâine, despre care Preafericitul Părinte Daniel, Patriarhul Bisericii Ortodoxe Române afirma că trebuie să redescopere legătura profundă dintre libertate și sfințenie.

In raport cu cosmosul, se observă deja consecințele unui comportament iresponsabil al omului postmodern. Avid după bunăstare, el generează și amplifică o criză ecologică de proporții, ale cărei consecințe sunt greu de anticipat pe termen mediu și lung. Aceasta îl afectează, în primul rând, pe om, dar și celelalte specii de animale și plante lăsate lui spre chivernisire și nu spre pieire și criză ecologică planetară.

Dezinteresul, am putea spune, criminal, al omului față de creația lui Dumnezeu, îl conduce pe acesta la nesupunere și neascultare, întrucât el a fost pus să stăpâneasca natura, nu să o distrugă. Cercetările asidue ale științei bine intenționate și tehnologiei actuale vădesc, în unele domenii, o atitudine potrivnică normelor creștine de morală pe care o substituie cu etica și bio-etica.

Aceleași pretenții creatoare se întâlnesc și în metodele de inginerie genetică neîngăduite de Biserică: fertilizarea in vitro și clonarea, unde ,joaca de-a Dumnezeu” duce la consecințe fatale, imprevizibile.

Globalizarea economică, politică și culturală - lumea este o imensa piață de desfacere, tot mai multe granițe dispar, se creează alianțe comerciale și militare mondiale, se pun la cale migrații de popoare sub pretextul îmbătrânirii populațiilor ca și cum agresiunea și nu iubirea stau la baza procreării. Planul spiritual se cere a-l urma îndeaproape pe cel material; de aceea, se încearcă a se crea un conglomerat din religii, tradiţii și culturi diferite. Inevitabil, se 
ajunge la sincretism, ca țintă ultimă a globalizării, ceea ce reprezintă categoric o trădare a Ortodoxiei.

Biserica nu este o realitate statică, ci una dinamică. De aici, rezultă și necesitatea continuării dialogurilor ecumenice, multilaterale, în vederea statornicirii unor principii misionare clare, care să gestioneze această sinergie între păstrarea neștirbită a Tradiției și adaptarea discursului la condițiile impuse de modernitate.

Se evită, astfel, două primejdii majore, dispuse antagonic: pe de o parte, o izolare care $n$-ar conduce decât la colapsul unui nedorit suicid, iar pe de alta, o topire a identității personale, incapabilă să se autodetermine în contextul unui sincretism absolut și definitiv. Iată pericolul la care sunt expuși cu preponderență tinerii din zilele noastre, tocmai de aceea este absolut necesar să luăm aminte la modelele propuse de Sfânta Scriptură și să medităm cu atenție la cuvintele Mântuitorului: Căci cine va voi să-și scape sufletul $\hat{l} l$ va pierde, iar cine va pierde sufletul Său pentru Mine și pentru Evanghelie, acela îl va scăpa (Marcu 8, 35) și Voi sunteți sarea pământului; dacă sarea se va strica, cu ce se va săra? De nimic nu mai e bună decât să fie aruncată afară și călcată în picioare de oameni. Voi sunteți lumina lumii (Matei 5, 13-14).

\section{Bibliografie}

1. ***BIBLIA SAU SFÂNTA SCRIPTURĂ, Bucureşti, Ediţia Sinodală, 1991.

2. I.P.S. Andrei Andreicuț, Dragoste, libertate și sex responsabil, Alba-Iulia, Editura Reîntregirea, 2001.

3. Sf. Evagrie Ponticul, Cuvânt despre rugăciune, în Filocalia, vol. 1 (ed. II), trad. de Pr. Prof. Dumitru Stăniloae, Sibiu, Insitutul de arte grafice „Dacia traiană", 1947.

4. Sf. Grigorie de Nyssa, Despre viaţa lui Moise, în „Scrieri ale Sfântului Grigorie de Nyssa", colecția Părinți și Scriitori Bisericești, vol. 29, trad. de Pr. Prof. Dumitru Stăniloae şi Pr. Ioan Buga, București, Editura Institutului Biblic și de Misiune al Bisericii Ortodoxe Române, 1982. 
5. Sfầntul Ioan Gură de Aur, „Cuvânt la Sfânta şi Marea Marţi: Împotriva lenevirii de a veni la Biserică", în Omilii la Postul Mare, Bucureşti, Editura Anastasia, 1997.

6. Părintele Iustin Popovici, Credinţa Ortodoxă şi viaţa în Hristos, Ediţie electronică, Apologeticum, 2006.

7. Kallistos Ware, Educaţia Teologică în Scriptură şi la Sfinţii Părinţi, traducere de Anişoara Carol, în Studii Teologice, Seria a II-a, XLVI, 1994, nr. 4-6.

8. Liviu Valentin Iftene și Ștefan Adrian Dinu, Oferta globalizării, articol din „Tinerii creștini și provocările globalizării”, Galați, Editura Episcopiei Dunării de Jos, 2005.

9. Mitropolit Dr. Nicolae Mladn, Tineretul și rugăciunea, articol din „Tineretul și creștinismul”, Craiova, Editura Mitropolia Olteniei, 2008.

10. Mitropolit Emilianos Timiades, Preot, parohie, innoire, articol din "Tinerii și Biserica în zilele noastre", Craiova, Editura Mitropolia Olteniei, 2008.

11. Nicolae Steinhard, Ispita lecturii, Cluj-Napoca, Editura Dacia, 2000.

12. Pavel Florenski, Stâlpul şi Temelia Adevăruluii, Editura Polirom, 1999.

13. Paul Evdokimov, Rugăciunea în Biserica de Răsărit, Iaşi, Editura Polirom, 1996.

14. Sorin M. Rădulescu, Sociologia vârstelor, Bucureşti, Editura "HYPERION XXI", 1994.

15. Vâlcu George, Tânărul creștin în contextul globalizării. Soluții pentru ieșirea din criză., articol în „Tinerii creștini și provocările globalizării”, Galați, Editura Episcopiei Dunării de Jos, 2005. 